\title{
Rapid Bridge Replacement under Emergency Situation: Case Study
}

\author{
Yong Bai, P.E., M.ASCE ${ }^{1}$; William R. Burkett, P.E. ${ }^{2}$; and Phillip T. Nash, P.E. ${ }^{3}$
}

\begin{abstract}
The terrorist attack on September 11, 2001, and subsequent potential threats to the United States transportation systems have presented an urgent need to elevate the security of the transportation infrastructure and to develop emergency response plans to quickly react to the possible consequences of an extreme event. Highway bridges, as critical components of the nation's transportation network, have been brought to closer attention by government agencies. A research project was conducted to identify strategies and technologies to restore the use of a damaged bridge quickly. One of the tasks associated with the research was to perform several case studies of previous bridge replacements following extreme events. These events include explosion and fire caused by vehicle impact, vessel collision with a bridge, and damage caused by flood and earthquake. By studying the cases, the research team seeks to identify and expand on lessons learned and address which actions did and did not work well given the circumstances of the incident. These lessons have great value to the people who need to develop and implement an emergency response plan.
\end{abstract}

DOI: 10.1061/(ASCE)1084-0702(2006)11:3(266)

CE Database subject headings: Bridge construction; Bridge design; Emergency services; Bridges, highway; Pennsylvania; Terrorism; Case reports; Replacement.

\section{Introduction}

The terrorist attack on September 11, 2001, and subsequent potential threats to the United States transportation systems have presented an urgent need to elevate the security of the transportation infrastructure and develop emergency response plans to quickly react to the possible consequences of an extreme event. Highway bridges, as critical components of the nation's transportation network, have been brought to closer attention by government agencies. A pooled-fund research project, titled "Rapid Bridge Replacement Techniques," was conducted from March 2002 to August 2003. One of the tasks associated with the research project was to conduct several case studies of previous bridge replacements following extreme events. These events included explosion and fire caused by vehicle impact, vessel collision with a bridge, and damage caused by flood and earthquake. The research team reviewed 26 bridge incident cases in the United States and abroad. A summary of these cases is presented in Table 1. From among these 26 cases, the research team identified three cases to perform in-depth studies: (1) the Interstate 95 (I-95) Chester Creek Bridge in Pennsylvania; (2) the New York

${ }^{1}$ Assistant Professor, Dept. of Civil, Environmental, and Architectural Engineering, Univ. of Kansas, 1530 W. 15th St., 2150 Learned Hall, Lawrence, KS 66045. E-mail: ybai@ku.edu

${ }^{2}$ Professor, Dept. of Engineering Technology and Civil Engineering, Texas Tech Univ., Lubbock, TX 79409.

${ }^{3}$ Senior Researcher, Dept. of Civil Engineering, Texas Tech Univ., Lubbock, TX 79409.

Note. Discussion open until October 1, 2006. Separate discussions must be submitted for individual papers. To extend the closing date by one month, a written request must be filed with the ASCE Managing Editor. The manuscript for this paper was submitted for review and possible publication on January 26, 2004; approved on July 15, 2005. This paper is part of the Journal of Bridge Engineering, Vol. 11, No. 3, May 1, 2006. CASCE, ISSN 1084-0702/2006/3-266-273/\$25.00.
State Thruway Bridge in New York; and (3) the Interstate 40 (I-40) Webbers Falls Bridge in Oklahoma. The reasons for which these bridges were chosen were that all were critical components on the nation's major interstate highways and that the incidents had significant impacts on the surrounding community. All three bridges had steel girders with concrete deck structures. Webbers Falls Bridge spans the Arkansas River in a rural area, while both the Chester Creek Bridge and the New York State Thruway Bridge are over land in urban areas. Due to the paper length limits, this paper presents only the partial findings of the research project associated with one detailed case study, the replacement of the I-95 Chester Creek Bridge in Pennsylvania.

\section{Research Objective}

The objective of the research was to identify strategies and technologies to restore the use of a bridge quickly in the event it is damaged or destroyed. A case study methodology was utilized to accomplish this objective. By studying previous cases, the research team sought to identify and expand on lessons learned, address which actions did and did not work well given the circumstances of the incident, and incorporate these lessons in emergency response plans.

\section{Case Study Methodology}

Case studies were conducted using a three-step approach. First, the research team reviewed the literature related to the cases, including newspaper articles, conference and journal papers, technical reports, and Web sites. Second, the research team interviewed the people who were involved in the case via telephone. These people came from state Departments of Transportation (DOTs), design firms, contractors, and material suppliers. In these 
Table 1. Case Summaries

\begin{tabular}{lcc}
\hline $\begin{array}{l}\text { Case } \\
\text { number }\end{array}$ & Title & Time \\
points
\end{tabular}

1 Ohio Bridge GUE-513-1.80, Quaker City, Ohio June $2003 \quad$ Cast-in-place concrete deck; scheduled deck replacement; replaced existing deck with posttension, precast, modular deck slabs; contract incentives used

$2 \quad$ FM 1927 over I-20, Ward County, Tex.

NASA Road 1, Houston
I-65/I-59 bridge replacement, Birmingham, Ala.

I-80 Bridge, Denville, N.J.

Hoan Bridge, Milwaukee

Lions' Gate Suspension Bridge, B.C., Canada

Brooklyn Bridge, New York

I-95 Chester Creek Bridge, Chester, Pa.

Braddock Road Overpass, Virginia

Wantagh Parkway Bridge, New York

New York Thruway Bridge, Yonkers, N.Y.

Century Road Overpass over Highway 16X, Canada

I-45/Pierce Elevated, Houston

Blake Street Bridge, New Haven, Conn.

Sava River Bridge, Bosnia

I-10 San Antonio "Y," San Antonio
January 2003

May 2002

April 2002

January 2002

June 2001

December 2000

December 2000

May 1999

April 1999

October 1998

May 1998

May 1998

April 1998

October 1997

June 1997

December 1996

April 1996

January 1996

March 1995
Four-span prestressed concrete beams over traffic; concrete deck; impact from overheight load; localized damage to external beam; repairs used epoxy injection, rapid set grout, and concrete

Four-span steel girder over water; concrete deck; concrete piers; barge impacted substructure; replaced steel girders with precast concrete; replaced piers; contract incentives used

Five-span noncomposite steel box beams; replaced to increase clearance; high strength concrete and rapid construction techniques used; contract incentives used

Three-span steel girders over traffic; gasoline tanker impact/ fire beneath deck; extreme sagging of steel girders; total replacement; contract incentives used

Simple-span concrete I-beams over water; explosion and fuel fire; cracking in five of six beams; temporary bridge used to detour traffic; steel I-beams used as replacement

Steel beams and girders over land; cold temperature, heavy loads, and construction flaws leading to beam failure; two of three beams suffered cracking; total span replacement; contract incentives used

Pin and hanger supported steel girders over water; concrete deck; cargo boom impacted superstructure and deck; damaged two girders and deck slab; damaged girder portions were removed and replaced using welding techniques; rebar replaced and new concrete placed

Steel beams with doubledeck over traffic; corrosion of steel beams; buckling of one beam; erected new support beams Steel superstructure; concrete deck; deterioration of deck; replaced deck and widened lanes

Steel superstructure (cable suspension); cast-in-place concrete deck; concrete and steel deterioration of deck; deck replacement using modular panels; contract incentives used Three-span steel girder over traffic; concrete deck; concrete piers; gasoline tanker impact/fire on deck; replaced steel girders

Concrete deck; concrete deterioration; deck replacement Original structure over water was closed and demolished; tidal scour damage created separation of piers from roadbed; installed panel bridge sections as temporary repair

One-span steel girder over traffic; concrete deck; gasoline tanker impact/fire under deck; temporary bridge used to detour traffic; total replacement

Prestressed bulb tee girders; impact from overheight load; damaged 15 of 18 girders; repairs included patching with epoxy resin, splicing tendons, recasting girders; contract incentives used

Existing bridge reached end of useful life and was demolished; total replacement using prefabricated members; contract incentives used

Three-span reinforced concrete beams over water; scouring of piers; failure of main pier supports; temporary bridge used to detour traffic; total replacement

29-span steel-truss over water and land; bomb damage from military operations; replaced four spans with panel bridges; repaired two piers

Posttensioned wing segmental design over traffic; cracking of two cantilever piers; temporary scaffolding used during repair 
Table 1. (Continued.)

\begin{tabular}{|c|c|c|c|}
\hline $\begin{array}{l}\text { Case } \\
\text { number }\end{array}$ & Title & Time & $\begin{array}{l}\text { Important } \\
\text { points }\end{array}$ \\
\hline 21 & Sagtikos Parkway Bridge, Long Island, N.Y. & October 1994 & $\begin{array}{l}\text { Four-span, rolled steel beams over traffic; concrete deck; } \\
\text { concrete piers; car/petroleum tanker collision and subsequent } \\
\text { fire under bridge deck; severe fire damage to beams, deck } \\
\text { and a pier; replaced span and pier; Inverset composite steel } \\
\text { beam units used in repair }\end{array}$ \\
\hline 22 & Judge Seeber Bridge, New Orleans & May 1993 & $\begin{array}{l}\text { Barge impacted substructure; collapse of one pier and two } \\
\text { spans; reconstructed bent superstructure and deck sections }\end{array}$ \\
\hline 23 & Bridge 8750 on the M20, United Kingdom & December 1992 & $\begin{array}{l}\text { Four-span prestressed concrete beams; cast-in-place concrete } \\
\text { slab; abutments and concrete portals; vehicle impacted portal; } \\
\text { spalling/cracking of portal; resin injection repair of concrete } \\
\text { damage }\end{array}$ \\
\hline 24 & Seneca River Bridge, Port Byron, N.Y. & $\begin{array}{c}\text { November } \\
1990\end{array}$ & $\begin{array}{l}\text { Single-lane bridge over water; snowplow blade impacted } \\
\text { vertical member; collapse of } 40 \mathrm{ft} \text { section; installed panel } \\
\text { bridge sections as permanent repair }\end{array}$ \\
\hline 25 & Route 78 bridge, New Jersey & December 1989 & $\begin{array}{l}\text { Steel stringers; concrete pavement; garbage fire under bridge; } \\
\text { catastrophic damage to structural elements beneath deck; } \\
\text { temporary bypass used to detour traffic; total replacement }\end{array}$ \\
\hline 26 & John Ross Bridge, South Africa & $\begin{array}{l}\text { September } \\
\quad 1987\end{array}$ & $\begin{array}{l}\text { Two-section prestressed concrete; extreme flood causing total } \\
\text { collapse; total replacement using incremental launching; } \\
\text { contract incentives used }\end{array}$ \\
\hline
\end{tabular}

telephone interviews, people were asked a series of questions regarding their roles in the case and their knowledge about the case. After the first two steps, the research team had an initial understanding about each case and unanswered questions were clearly outlined. The third step was to conduct a survey to gain knowledge about the previously unanswered questions and additional information related to each case. The survey questionnaire consisted of five aspects, including the contracting method, engineering, construction, state DOT's support, and material supplier and vendor. A sample survey questionnaire is shown in the Appendix.

There are several reasons for choosing the survey method to acquire knowledge. First, a survey is a relatively easy way to solicit answers to the same questions from several people. Second, a survey questionnaire provides, in general, a very clear statement of problems. Third, a survey gives people more time to respond to the questions as compared to personal interviews. Fourth, survey results are easy to compare and analyze. At the end of each case study, a report was generated including the lessons learned. This paper only presents the I-95 Chester Creek Bridge case and lessons learned due to the maximum paper length limits.

\section{I-95 Chester Creek Bridge Incident}

At about 7:00 a.m. on Saturday, May 23, 1998, a gasoline tankertruck owned by the Samuel Coraluzzo Company of Vineland, N.J., hauling 32,930 L (8,700 gal.) of fuel and traveling northbound on I-95, crashed through the concrete median barrier and exploded after striking a pickup truck traveling southbound on I-95 on the bridge over Chester Creek in Delaware County, Pa. The explosion caused a fireball, and the charred bridge buckled under intense heat, exceeding $1,093^{\circ} \mathrm{C}\left(2,000^{\circ} \mathrm{F}\right)$. The Pennsylvania Department of Transportation (PennDOT) immediately closed I-95's three northbound and three southbound lanes between Interstate 476 (I-476) and State Route 452, due to fear that the bridge might be unsafe for the traveling public. The timing of the accident could not have been worse, because it was the start of the Memorial Day holiday weekend. Traffic backups stretched for miles as motorists clogged alternate routes. The fire-damaged bridge on I-95 normally carries 80,000 vehicles per day and is among the most heavily traveled corridors in the United States (Burns 1999). The incident resulted in two deaths and one injury (Jennings et al. 1998).

\section{Damage Assessment}

The 110-m-long (360 ft), three-span continuous bridge was built by Buckley \& Company, Inc., of Pennsylvania in 1965. The superstructure of the bridge includes steel girders and frames with a concrete deck. The steel girders were supported by concrete piers. There are three traffic lanes in both the northbound and southbound directions. PennDOT bridge engineers evaluated the bridge just after the accident and declared that the southbound structure was unsafe due to severe damage caused by the fire and that the northbound structure was undamaged. The flames scorched most of the 110-m-long (360 ft) concrete deck and caused the steel superstructure to sag, but not collapse. Three of the four 110 -m-long (360 ft) steel girders on the bridge had damaged sections. Each girder was composed of five segments welded together. Three segments on each of the three damaged girders required replacement, totaling nine girder segments under the southbound lanes of the bridge that were damaged. Each girder segment was $2 \mathrm{~m}$ ( $6 \mathrm{ft} 8 \mathrm{in}$.) high and between 20 and $24 \mathrm{~m}$ (65 and $80 \mathrm{ft}$ ) long and required special fabrication, along with reinforcing rebar and steel pans for the bridge deck. Part of the concrete deck needed to be torn down and rebuilt. Approximately two-thirds of the superstructure needed to be replaced. The foundation of the bridge was not damaged. The substructure had one pier that required some minor concrete repairs.

\section{Detour and Temporary Transportation}

PennDOT established detours for northbound and southbound traffic as soon as it closed I-95's three northbound and three southbound lanes between I-476 and State Route 452. Southbound drivers were instructed to exit I-95 at I-476, take I-476 north to exit 3, travel Route 1 south to Route 452, and then follow it south back to I-95. Southbound long-distance travelers were to 


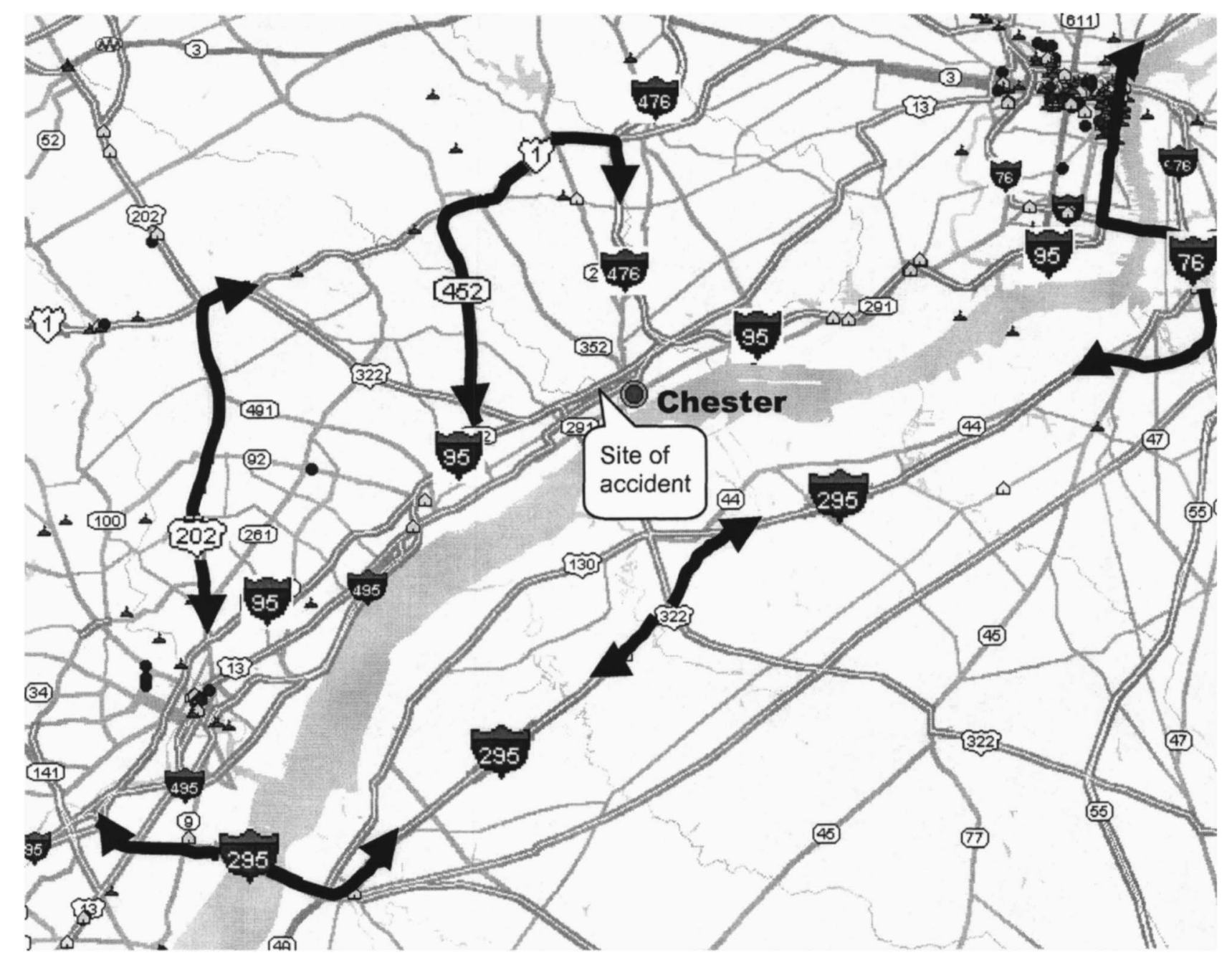

Fig. 1. Detour map

take exit 15 at I-95 to Interstate 76 (I-76) east over the Walt Whitman Bridge, then exit 1A for Interstate 295 (I-295) south over the Delaware Memorial Bridge and back to I-95. Northbound drivers were instructed to take Route 452 north to U.S. Route 1 north, then go to I-476 south and back to I-95, or take Route 202 north to U.S. Route 1 north to I-476 south and back to I-95. PennDOT instructed northbound long-distance travelers to bypass the area entirely by taking I-295. The detour map is presented in Fig. 1.

The Governor of Pennsylvania declared a disaster emergency just hours after the crash. The declaration allowed government agencies such as PennDOT to expedite their response to the accident in order to protect public health and safety. The declaration set aside the normal government constraints, allowing agencies to hire, purchase, and contract without following standard government rules and regulations. The Secretary of PennDOT immediately awarded the replacement contract to Buckley \& Company, Inc., who built the original bridge and had previously successfully performed a similar replacement project. The replacement work included two major parts. First, the contractor built four temporary traffic lanes so as to reopen I-95 to the traveling public before Monday, May 25. Second, the contractor replaced the damaged bridge sections and reopened six lanes of I-95 by July 15, 1998 (the original finish date). Buckley was paid on a time-and-materials (force account) basis with markups specified in PennDOT's standard specifications, PUB 408. Subcontractors were also paid on a time-and-materials basis, and Buckley received an $8 \%$ markup on top of the subcontractors' costs. All overtime wages were paid directly with the standard PennDOT markup of $40 \%$ applied labor. Material suppliers were paid using lump sum contracts.

Building of temporary traffic lanes began Saturday evening on May 23. Buckley, along with several subcontractors and PennDOT crews, made temporary crossovers. Nearly 200 construction workers labored throughout Saturday night and for much of Sunday to remove about 140 concrete median barriers. Each barrier was 0.9-m-high (34 in.) and weighed 1.8 mega grams (2 tons). A $1.2 \mathrm{~km} \mathrm{(3/4} \mathrm{mi)} \mathrm{stretch} \mathrm{was} \mathrm{modified}$ to carry two lanes in each direction using the northbound side of the I-95. The width of each lane was $3.4 \mathrm{~m}(11 \mathrm{ft})$ instead of the normal width of $3.7 \mathrm{~m}(12 \mathrm{ft})$. Two temporary lanes of northbound I-95 opened to traffic on Sunday, May 24, at 1:15 p.m. At 3:55 p.m. on the same day, two temporary southbound lanes reopened to the traveling public. A $40 \mathrm{mph}$ speed limit was implemented and monitored closely by state police. With four temporary lanes in service before Monday, May 25, when substantial increases of holiday traffic would occur, PennDOT and Buckley shifted their focus to replacing the 110-m-long (360 ft) three-span continuous bridge. 


\section{Design for Replacement}

The replacement was identical to that of the original bridge, which was designed by Sanders \& Thomas, Inc., a design firm in Florida. The shop drawings necessary for fabrication were found in PennDOT's bridge archives and provided to Buckley immediately. Because the replacement work used the original shop drawings, there was no need for PennDOT to approve the drawings. This saved considerable time during the replacement process. Some requirements in the standard specifications were waived based on solid engineering judgments in order to expedite the replacement process. For example, all time-based specifications for concrete maturity were waived and $50 \%$ of the ties in the bottom rebar for the bridge deck were waived.

\section{Bridge Replacement}

The entire replacement was conducted in three stages: demolition, material preparation, and reconstruction. Demolition and material preparation were performed simultaneously. On May 29, Buckley along with the Eastern-States Wrecking Company started to remove the $16-\mathrm{m}$-wide $(52 \mathrm{ft}$ ) concrete deck. This work was completed by June 2. Over the next two days, crews removed nine damaged steel girder segments and set the stage for reconstruction. Demolition was carried on 7 days per week and 12 hours per day.

Shortly after receiving the replacement contract, Buckley contacted High Steel Structures, Inc., of Lancaster, Pa., on Sunday, May 24, to determine if the company could fabricate the replacement girder segments with cross frames under the very tight schedule. Fabrication and delivery of the steel beams were the critical activities in the replacement process. The response from High Steel was yes. To meet the schedule requirement, which was to deliver the nine girder segments by June 15, High Steel planned to work around the clock and reschedule other work. On May 26, after examining the bridge drawings, High Steel ordered the steel material needed for the replacement girder segments from the Bethlehem Steel Plant in Sparrows Point, Md. The response from Bethlehem Steel was also very quick. On Friday, May 29, High Steel was able to begin taking delivery on the steel plate. That night, High Steel production crews began working 24 hours a day, 7 days per week, on the project. The fabrication of nine girder segments, each 20-24 m (65-80 ft) long, standing $2 \mathrm{~m}$ (6 ft 8 in.) high, and weighing 14-18 megagrams (15-20 tons), was completed in only 10 days. This accomplishment was 7 days ahead of the original delivery date of June 15 (Carey 1998b). Normally, this amount of fabrication work would take 3-4 weeks to complete. Under Pennsylvania state law, High Steel could only ship one girder per load. A special permit was granted by the Governor to allow High Steel to deliver three girders per load in order to expedite the reconstruction.

Buckley installed the nine steel girder segments on June 8 and 9. Fig. 2 shows a piece of steel girder being placed on a concrete pier cap. Then, construction crews set 4.3 -m-wide (14 ft) steel deck pans between the four rows of girders. Next, reinforcing bars were installed in place for the concrete deck. A total of 38 truckloads of concrete were placed to form the new $254 \mathrm{~mm}$ (10 in.) deck on Tuesday, June 16. Fig. 3 presents the new concrete bridge deck. While the concrete cured, construction crews poured new parapet walls on the bridge. The compressive strength of the concrete deck exceeded the required 27,560 kilopascals $(4,000$ psi) less than a week after the deck pour. On June 25,

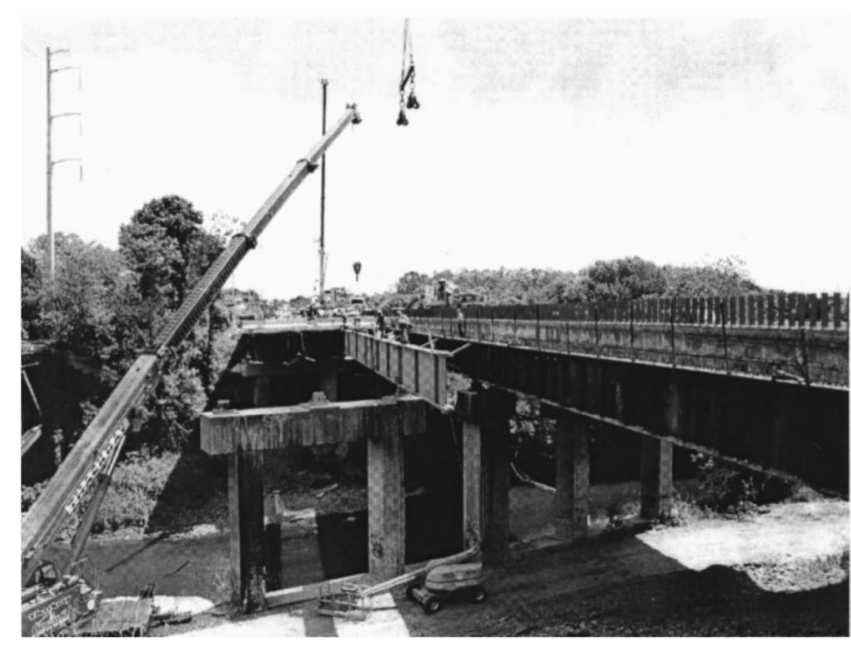

Fig. 2. Placing steel girder on concrete pier cap

PennDOT moved two lanes of traffic back to southbound I-95 before the start of the morning rush (Carey 1998a). Interstate Safety Services of Clarks Summit, Pa., supplied 854 m (2,800 ft) of new concrete barriers to replace the road's central median on June 27, two days ahead of schedule. Installation of the median started the following day. During the reconstruction process, construction was conducted 12 hours per day, 7 days per week. Because of the good weather, hard work, and quick delivery of supplies, the bridge was reopened to the public on June 29. Buckley continued to perform structural work underneath the bridge after the traffic had been restored. All repair work was completed on Friday, July 3, 12 days ahead of the original target date of July 15. Based on past experience, similar repair work could require approximately 6 months under normal conditions. If using conventional bidding procedures, the entire repair process could take even longer. Table 2 presents the major events occurring during the replacement process. Officials from PennDOT stated that the repair project cost less than the original $\$ 4,000,000$ estimate. Buckley received $\$ 500,000$ in overtime pay.

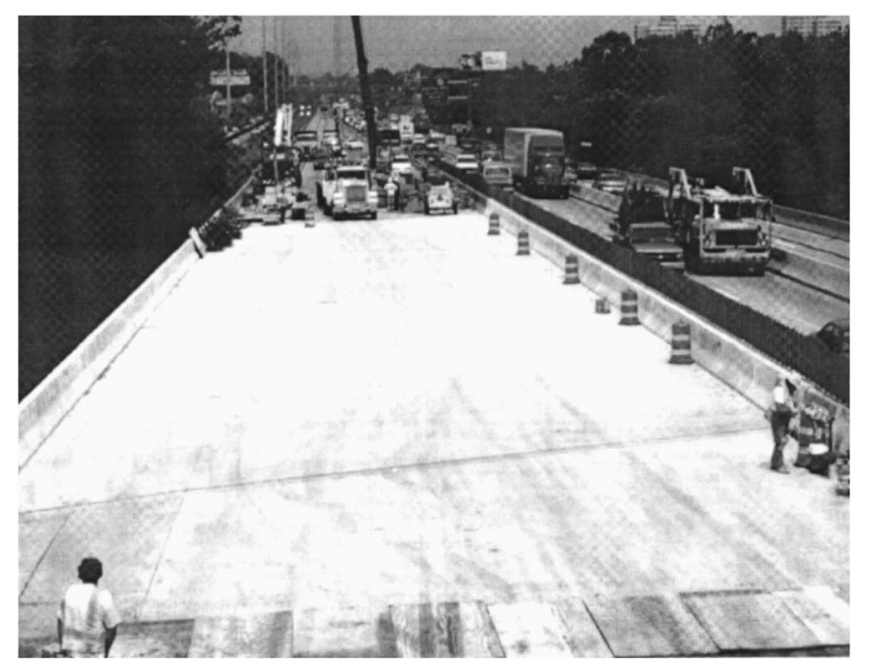

Fig. 3. New concrete deck 
Table 2. Dates for Major Replacement Events

\begin{tabular}{|c|c|}
\hline Date & Events \\
\hline $05 / 23 / 98$ & Accident occurred \\
\hline $05 / 23 / 98$ & $\begin{array}{l}\text { PennDOT awarded repair contract } \\
\text { to Buckley \& Company, Inc. }\end{array}$ \\
\hline $05 / 24 / 98$ & $\begin{array}{l}\text { Two temporary lanes in each direction } \\
\text { opened to traveling public. }\end{array}$ \\
\hline $05 / 24 / 98$ & $\begin{array}{l}\text { Buckley awarded steel girder fabrication } \\
\text { to High Steel Structure, Inc. }\end{array}$ \\
\hline $05 / 26 / 98$ & $\begin{array}{l}\text { High Steel ordered steel material } \\
\text { from Bethlehem Steel. }\end{array}$ \\
\hline $05 / 29 / 98$ & High Steel started to receive steel plates. \\
\hline $05 / 29 / 98$ to $06 / 02 / 98$ & Demolition of 16-m-wide concrete deck. \\
\hline $06 / 03 / 98$ to $06 / 04 / 98$ & $\begin{array}{l}\text { Removal of nine sections of fire-damaged } \\
\text { steel girders. }\end{array}$ \\
\hline 06/07/98 & $\begin{array}{l}\text { Fabrication of nine girder segments } \\
\text { was completed. }\end{array}$ \\
\hline $06 / 08 / 98$ to $06 / 09 / 98$ & Buckley installed steel girders. \\
\hline 06/16/98 & New $254 \mathrm{~mm}$ concrete deck was poured. \\
\hline $06 / 25 / 98$ & $\begin{array}{l}\text { PennDOT moved two lanes of traffic back } \\
\text { to southbound I-95. }\end{array}$ \\
\hline $06 / 27 / 98$ & $\begin{array}{l}\text { Interstate Safety Services delivered } 854 \mathrm{~m} \\
\text { concrete road median. }\end{array}$ \\
\hline $06 / 28 / 98$ & $\begin{array}{l}\text { Installed concrete road median and marked } \\
\text { traffic lanes. }\end{array}$ \\
\hline $06 / 29 / 98$ & Bridge was reopened and traffic was restored. \\
\hline 07/03/98 & $\begin{array}{l}\text { Entire repair work finished, } 12 \text { days ahead } \\
\text { of original schedule. }\end{array}$ \\
\hline
\end{tabular}

\section{Lessons Learned}

There were many factors contributing to the success of the replacement project. In order to document what can be learned from this project, the research team conducted this case study. During the study, the research team reviewed literature including information posted on Web sites, interviewed people involved in the repair project via the telephone, and performed surveys. The survey questionnaire was sent to PennDOT and Buckley \& Company, Inc. The survey consisted of questions in five aspects including contracting method, engineering, construction, PennDOT support (to Buckley only), and material supplier and vendor. Notwithstanding its terrible consequences, the I-95 Chester Creek Bridge incident provides useful lessons for government agencies that must plan for enhanced responses in case of future incidents. The following summary outlines lessons learned during the replacement of the bridge:

1. The Secretary of PennDOT was able to award the repair contract without bidding it, under the state emergency declaration. This saved considerable time for reconstruction of the bridge.

2. Use of established contracting documents, which in this case was the time and materials plus markup percentages that are specified in PennDOT's standard specifications, PUB 408, expedited the contracting negotiation process and avoided future contracting disputes.

3. Temporary traffic lanes should be constructed first and made available to the traveling public as soon as possible. Doing this will reduce the pressure of traffic congestion and ease the inconvenience to the traveling public.
4. Utilizing the state police to enforce the speed limit in the temporary traffic lanes provided a safe environment for bridge repair activities.

5. Plans and shop drawings were available in PennDOT's bridge archives and were provided to the contractor and material suppliers immediately. Without the complete plans and drawings, the repair process could have taken much longer.

6. Some requirements of the specifications, such as time-based specifications for concrete maturity and $50 \%$ ties in the bottom rebar for the bridge deck, were waived based on solid engineering judgments to expedite the repair process.

7. Commitment and dedication of the necessary resources from all the parties made the repair project a success. Buckley had ample resources to complete the work, which was one of the main reasons PennDOT selected Buckley to do the replacement work. PennDOT's chief construction engineer was on site all the time, so decisions were made quickly without a formal submission process.

8. The most critical activity in the repair process was the fabrication of the steel beams. The steel fabricator rearranged the existing fabrication schedules and worked 24 hours per day, 7 days per week, to support the project. The standard inspection functions required on PennDOT projects were performed at the steel plant and fabrication shop. Those beams were delivered ahead of the original anticipated schedule.

9. Under Pennsylvania state law, the material supplier was allowed to ship only one steel girder per load. To expedite the reconstruction, the Governor of Pennsylvania granted a permit that allowed the supplier to ship three girders per load. The effort not only accelerated the material delivery but also saved cost.

10. The general contractor and subcontractors were very organized and efficient. Numerous repair operations were conducted concurrently. The general contractor had great confidence in the performance of the subcontractors and material suppliers.

11. PennDOT took the responsibility of dealing with the media and let the general contractor and subcontractors focus on their repair work.

Although the replacement project was finished 12 days ahead of the original schedule with a good quality and safety record, there were areas that could be improved in the future. Considerations for future improvements are summarized as follows:

1. Options for using a competitive bid process to select a contractor to do the replacement work should remain open, so that qualified contractors will have an equal opportunity to participate in emergency replacement work. However, the duration of the bidding process should be kept short. This means that state DOTs need to prepare bid packages quickly (e.g., within $24 \mathrm{~h}$ ) and contractors need to bid the repair work fast (e.g., within $24 \mathrm{~h}$ ). In order to shorten the bid process, state DOTs should develop emergency procurement/contracting procedures and documents and identify the qualified contractors for emergency work in advance.

2. Durations of emergency bridge replacement projects need to be estimated more accurately. This requires state DOTs and contractors to collect productivity data and conduct schedule analysis. 
3. There is a need to continue to search for new construction technology that could speed up the reconstruction process. One of the areas that has potential is nighttime bridge construction. Nighttime construction accelerates the replacement process and reduces the inconvenience to the traveling public. To fully utilize the benefits of this technique, several issues must be studied, including sleep deprivation, fatigue, stress, poor visibility, irregular eating routine, and social/ domestic issues.

\section{Conclusions and Recommendations}

After the 9/11 terrorist attack, rapid bridge replacements after extreme events have been brought to closer attention by government agencies and engineering and construction communities. This paper addresses the rapid bridge replacement process and construction techniques through a detailed case study of the replacement of the I-95 Chester Creek Bridge in Pennsylvania. The southbound bridge structure was damaged due to a huge fire caused by a collision between a gasoline truck and a pickup truck, and it was replaced under an emergency situation. The process of bridge replacement included temporary traffic management (e.g., detour routes), demolition of the damaged structure, replacement design, material preparation, and bridge reconstruction. During the replacement process, various construction engineering and management techniques were employed to minimize impacts to the traveling public and surrounding communities and to accelerate overall replacement schedules. These techniques are as follows: (1) etablishing temporary traffic quickly for the traveling public; (2) utilizing a 12 hours per day, 7 days per week, construction schedule; (3) waiving time-based specifications for concrete maturity using solid engineering judgments; (4) having an incentive/disincentive clause in the construction contract; and (5) changing normal operational procedures (e.g., expediting the review and approval process for shop drawings). Because of these techniques, the I-95 bridge was replaced just 41 days after the incident. Under normal conditions, it would have taken approximately 6 months. Although the replacement project was finished ahead of the original schedule with a good quality and safety record, there are areas that could be improved in the future to make the replacement process even better. These areas include: (1) providing equal opportunity to qualified contractors to participate in emergency replacement work; (2) collecting productivity data so that the bridge reconstruction schedule can be estimated more accurately; and (3) continuously searching for new construction technology that could speed up the bridge reconstruction process.

\section{Acknowledgments}

The writers would like to thank Mr. Rex Mackey of PennDOT; Mr. Robert Buckley, Mr. Craig Hoogstraten, and Mr. David Warner of Buckley \& Company, Inc.; and Mr. Steve Bussanmas of High Steel Structures, Inc., for their vital input and cooperation during the case study. A special thanks goes to the state DOTs who provided financial support and guidelines for this research project. These DOTs included Georgia, Illinois, Minnesota, Mississippi, New Jersey, Iowa, Ohio, South Carolina, and Texas.

\section{Appendix. Survey Questionnaire}

\section{Contracting Method}

1. What contracting method was used to repair the bridge?

2. What kind of financial incentive method did PennDOT use to speed up the repair project? Was the incentive method effective? What other kind of incentive methods might be used to speed the repair process?

3. Did Buckley \& Company subcontract any portion of work to subcontractors? If yes, what contracting method was utilized?

4. What kind of financial incentive method did Buckley \& Company use in the contracts with the subcontractors and vendors/suppliers? Was the incentive method effective? What other kind of incentive methods might be used?

\section{Engineering}

1. What is the name and address of the firm who designed the I-95 Chester Creek Bridge? Did Buckley get the drawings from the design firm or PennDOT for the repair work?

2. What requirements in the specifications were waived based on engineering judgments in order to expedite the repair process?

3. What is the type of bridge foundation? Was the foundation damaged in any way?

\section{Construction}

1. Did Buckley \& Company work 24 hours/day, 7 days/week during demolition? If not, what were the work hours per day?

2. Did Buckley \& Company work 24 hours/day, 7 days/week during replacement of the bridge (e.g., install new girders, pour concrete deck, and so on)? If not, what were the work hours per day?

3. What kind of new construction technologies and methods were developed and implemented in the repair project?

4. What were the most difficult challenges during the repair process?

5. Under normal conditions, how long would it have taken to finish the repair project?

6. What were the major reasons why Buckley \& Company was able to finish the repair project early (e.g., more resources, new construction technologies)?

7. People working on night shifts may face problems such as sleep deprivation, fatigue, stress, poor visibility, irregular eating routine, and social/domestic issues. These problems may result in low productivity and accidents. How did Buckley \& Company address these problems during the repair process?

8. In an emergency repair situation, nighttime construction is necessary because of the time issue. Is there a need to conduct a study on nighttime construction? For example, what is the appropriate safety standard or procedure during nighttime construction? How can productivity be improved during nighttime construction? What topics do you think need to be addressed for nighttime construction?

9. If a similar incident happens in the future and Buckley \& Company is responsible for repairing the bridge, what different actions will the company take from a construction standpoint?

10. When was the repair work complete? June 29 or July 3 ?

11. Can you provide us with any photographs taken during the repair process? 


\section{PennDOT Support}

1. What kind of support from PennDOT during the repair project was very helpful?

2. What kind of support/help would you like to have from PennDOT, but PennDOT didn't provide last time?

3. Were there any steps, if taken by PennDOT or the contractors, that could have finished the repair project faster?

\section{Material Supplier and Vendor}

1. Were the material suppliers/vendors able to provide the materials according to the construction schedule?

2. What were the difficulties that the material suppliers/vendors faced during the repair project?

3. What actions had been taken to ensure the quality of the materials under this circumstance?
4. What actions were taken to expedite material delivery under this circumstance?

5. Was it possible that Buckley \& Company might have finished the repair project earlier if material suppliers/vendors had improved their performance?

\section{References}

Burns, M. J. (1999). "Outstanding engineering in the Delaware Valley." Philadelphia Business J., Advertising Supplement, Feb. 19, 9.

Carey, K. E. (1998a). "I-95 repair work rolls along." Daily Times of Delaware County, 243(273), June 25, 3.

Carey, K. E. (1998b). "The quick fix." Sunday Times of Delaware County, 243(290), July 12, 41.

Jennings, J. W., Farrell, J., and Goodman, H. (1998). "Crash kills 2, blocks off I-95 traffic." Philadelphia Inquirer, May 24, A1 and A19. 